> Gi respons på artikler gjennom artiklenes kommentarfelt på tidsskriftet.no.

Innleggene publiseres fortløpende på Tidsskriftets nettside og et utvalg

av innleggene publiseres også i papirutgaven i spalten «Brev til redaktøren».

Redaksjonen forbeholder seg retten til å foreta redaksjonelle endringer.

Forfattere av vitenskapelige artikler har tilsvarsrett, jf. Vancouver-gruppens regler.

\section{Re: Dyrevelferdsloven bør utvides til også å omfatte barn}

Dersom Tidsskriftet ønsker å heve saklighetsnivået i omskjæringsdebatten, er vel ikke innlegget fra en veterinær i nr 102014 akkurat innertier (1)? Vi feirer 1814, og skammer oss grundig over en spesiell paragraf - «jødeparagrafen» - som holdt stand altfor mange år. Og blant denne lille gruppen norske statsborgere, som igjen opplever økende stigmatisering og hets, er det i Norge ca. fem guttebarn pr. år som omskjæres på sin åttende dag. Dette representerer en pakt fra Abrahams tid som er helt vital for jødene. På verdensbasis omskjæres ca. $96 \%$ av alle guttebarn av jødisk slekt enten man er ateist eller praktiserende jøde! Komplikasjonsfrekvensen angis til 0,2\%, og den vanligste komplikasjonen er lett forlenget blødning, i følge Ervin Kohn (2).

Denne pakten og praksisen er et eksistensielt anliggende! Et forbud er å erklære: «Du er uønsket!» Er det det vårt aktive meningshierarki ønsker? Det som er svært merkelig, er manglende spørsmål og undring, for ikke å si ydmykhet, - og aller mest den store hybris som demonstreres. Barneombudet og hennes meningsfølge kan ligne Tante Sofie. «Hvis bare alle var som jeg, da ville alt bli bra!».

Med henvisning til Koranen sura 5: 60 blir jødene i svertekampanjer ganske enkelt betegnet som «sønner av aper og griser». Mattilsyn og veterinærer?

\section{Per Arne Norum}

panorum@me.com

Per Arne Norum (f. 1936) er pensjonert lege.

Ingen oppgitte interessekonflikter.

\footnotetext{
Litteratur

1. Berge GE. Dyrevelferdsloven bør utvides til også å omfatte barn. Tidsskr Nor Legeforen 2014: 134: 1029
}

2. Moum AV. Utrop.no. http://www.utrop.no/Nyheter/Innenriks/23171 (23.6.2014).

\section{G.E. Berge svarer:}

Påstander om at å hindre omskjæring er et angrep på jødisk, muslimsk eller amerikansk kultur, er en avsporing av debatten. Enhver gutt/ mann, om han er jødisk, muslimsk eller amerikansk, har selvsagt rett til å la seg omskjære når han er gammel nok til å bestemme selv.

Å stå opp for nyfødte barns rettigheter basert på prinsipielle menneskerettigheter diskriminerer ingen, men setter likelydende etiske krav til alle, uansett rase, religion og nasjon. Å være opptatt av menneskerettigheter omfatter bevisst kamp mot all undertrykkelse og forfølgelse på alle plan, også av jøder, muslimer og amerikanere.

Religionsfrihet innebærer at man kan vedkjenne seg hvilken religion man vil. At man har rett til å tro på hva man vil, og utøve sin religion uten diskriminering, og bruke sin kropp til tilbedelse som man vil. Men hvor stopper din religionsfrihet og hvor starter min når de møtes?

Når det gjelder aktive fysiske handlinger, stanser din trosfrihet ved hudoverflaten der din kropp stanser, og før den treffer min hud, der jeg begynner. Der gjelder min trosfrihet. Akkurat som for alle andre menneskerettigheter.

Når det gjelder å påvirke kroppen fysisk, må du gjerne skade din egen kropp, og skjære av deg deler av tissen din hvis du mener det kreves av din gud. Men du får ikke skjære deler av min kropp, og langt mindre nyfødte barns. For min kropp gjelder min trosfrihet, ikke din eller samfunnets. På samme måte omfatter foreldres tros- frihet deres egen kropp, men ikke deres barns. Prinsippet om trosfrihet gir aldri en utvidet rett til å skade andre individers kropp for å tilfredsstille egen tro, enten det går utover barn, voksne eller dyr.

Et overgrep innebærer at et individ ut fra egne behov påfører et annet individ krenkelse, smerte, skade eller død. Dette individet må leve med de negative konsekvensene av handlingene til det første. $\AA$ amputere en frisk kroppsdel fra et friskt, men forsvarsløst individ som ikke kan protestere, på grunnlag av et religiøst, kulturelt eller tradisjonsbetinget ønske fra et annet individ, mener jeg er et overgrep ut fra våre menneskerettighetsprinsipper. Slike valg skal kun gjelde egen kropp, ikke andres.

Tradisjon gir ingen legitimitet hvis tradisjonen bryter vedtatte etiske samfunnsnormer eller menneskerettighetene. Dette gjelder uansett hvor gamle tradisjonene er, eller hvor mange som følger dem. Mennesket har årtusen lange tradisjoner med å undertrykke kvinner, befolkningsgrupper, barn, dyr etc. Dette legitimerer ikke slik undertrykking. Moderne etikk, basert på kristen etikk, humanistisk arv og menneskerettighetene, slår fast at ethvert individ $i$ en moderne rettsstat har krav på beskyttelse mot fysiske overgrep mot egen kropp enten de er store eller små, og enten de er utført av amatører, eller satt i system i helsevesenet. Så må vi velge: Skal grunnleggende menneskerettigheter eller tradisjon og eldgamle offerritualer veie tyngst?

\section{Geir Erik Berge \\ geb@lifeline.no}

Geir Erik Berge (f. 1957) er dyrlege ved Nordberg dyreklinikk i Oslo. Ingen oppgitte interessekonflikter.

\section{Re: Klokt forslag om aborthenvisning}

Jeg er enig i mye av det Kristoffersen skriver i sin kommentar om abortvalget for kvinner og legens rolle i denne sammenhengen (1). Spesielt er jeg enig i at legen ikke skal gi kvinnen konkrete råd, men hjelpe henne med å finne den rette beslutningen for henne. Derfor faller jeg også av i siste avsnitt når Kristoffersen samtidig skal bringe inn legenes personlige etiske oppfatninger som en del av beslutningen. Er det ikke innlysende at leger sender et signal når de har reservert seg? Hvordan kan leger ha en nøytral rolle i kvinnens beslutning hvis han eller hun i forkant har avvist sin tjeneste dersom kvinnen ønsker abort? Jeg støtter meg til Allmennlegeforeningen og Norsk forening for allmennmedisin i denne saken. Hensynet til den abortsøkende kvinnen må komme først.

Jeg mener regjeringens nye forslag, hvor allmennleger ikke lenger skal henvise abortsøkende, innskrenker handlingsfriheten både for legen og for kvinnen.

\section{Andreas Wahl Blomkvist}

andreas.wahl@gmail.com

Andreas Wahl Blomkvist (f. 1989) er medisinstudent ved Aalborg universitet.

Ingen oppgitte interessekonflikter.

\section{Litteratur}

1. Kristoffersen A. Klokt forslag om aborthenvisning. Tidsskr Nor Legeforen 2014 134: 1131 